\title{
IMPROVING OF SOFT CLAY SOIL AROUND TUNNEL OPENNING USING STONE COLUMNS AND ITS EFFECT ON THE BEHAVIOR OF TUNNEL LINING
}

\author{
Mostafa Abdou Abd El-Naiem \\ Civil Engineering Department, Assiut University, Assiut, Egypt \\ Civil Engineering Department, Al-Jouf University, KSA
}

\section{(Received June 13, 2011 Accepted July 26, 2011)}

The increasing demand for new infrastructure developments has recently led to an escalating trend to develop sites with inadequate ground conditions that were previously considered uneconomical to develop. These situations have posed challenged that geotechnical engineers are meeting by cultivating innovative techniques like stone columns to overcome soft clay soil conditions. Among the various methods for improving in situ ground conditions, stone columns are considered one of the most versatile and cost-effective ground improvement techniques. Stone columns reinforce cohesive soils and densify granular soils in order to increase bearing capacity and decrease total and differential settlement. The accuracy of the results obtained depends on the knowledge of the input data for the tunnel and the surrounding soil. Many geotechnical challenges are expected to occur related to soft clay soil stability and tunnel lining. One of these problems is expected to occur related to tunnel lining stability and surrounding soil is the high values of settlement due to compressibility of soft layer when it lies around or below tunnel lining.

This present study aims to improve the behavior of tunnel lining and eliminate the effect of soft clay layer on this behavior by using vertical stone columns. This study is carried out by using Finite Element Method. The tunnel lining is meshed with two dimensional elements, called BEAM 6 element. The soil and stone columns are meshed with another two dimensional elements called LST, (Linearly Varying Strain Triangular Element). In this study, the main parameters were taken into consideration are the position and properties of stone columns. It can be concluded that using of stone columns in tunnel opening zone has strong effect on the improving behavior of tunnel lining. For application of this study, data of Cairo Metro Tunnel- Line 2, was chosen. The results of this study were compared with the initial values obtained from case of does not include stone columns.

KEYWORDS: IMPROVE, SOFT CLAY, LAYERED SOIL, STONE COLUMNS, TUNNEL, FORCES, DEFORMATION, F.E.M.

\section{INTRODUCTION}

The development of tunneling projects under heavily populated cites such as Cairo, Riyadh, and ....etc. has been rapidly increasing around the world last decades. Since tunnel construction can have disastrous effect on buildings, neighboring structures, and 
utilities near the excavation, suitable construction methods and precautions have necessary to provide maximum safety inside and outside the tunnel. The increasing demand for new infrastructure developments has recently led to an escalating trend to develop sites with inadequate ground conditions that were previously considered uneconomical to develop. These situations have posed challenged that geotechnical engineers are meeting by cultivating innovative techniques like stone columns to overcome problematic soil conditions. Stone columns are relatively stiff with respect to the surrounding ground. Stone columns are columnar elements of highly compacted aggregate materials often installed in weak in-situ soils or fills. So, stone columns reinforce cohesive soils and densify granular soils in order to increase bearing capacity, decrease total and differential foundation settlement, provide vertical drainage pathways to increase the time rate of consolidation settlement, greater slope stabilization, reduce the potential for liquefaction, and allow construction on fills and soft soil layers. Aiban mentioned that, the fieldwork prior to and after the installation of stone columns consist of Cone Penetration Test (CPT), Standard Penetration Test (SPT), seismic cross-hole test and full-scale Plate-Loading Test, and results have shown that the rigidity of the plate for the full-scale Plate-Loading is critical for the evaluation of the efficiency of the ground improvement technique [1]. Depty et al. stated that, the influence of column material in the performance of stone column is studied through laboratory experiments on model stone columns installed in clay, where five reinforcement materials were studied: stones, gravel, river sand, sea sand and quarry dust. Load versus settlement response was determined. The grain size of the stone column material is one of the main controlling parameters in the design of stone columns. They found that stones are the most effective stone column material [2]. Also, they found that the degree of improvement of a soft soil by stone columns is due to two factors, the first one is inclusion of a stiffer column material in the soft soil, and the second factor is the densification of the surrounding soft soil during the installation of the stone column itself and the subsequent consolidation process occurring in the soft soil before the final loading of improved soil. Spacing of the column also plays an important role in the performance of stone columns. Several researchers have worked on theoretical, experimental and field study on behavior of stone columns. Ambily and Ganndi (2006) carried out a detailed experimental study on behavior of single column and group of seven columns by varying parameters like spacing between the columns, shear strength of soft clay and loading conditions [3]. They presented improvement factor without considering stress due to installation of stone column. Andreou et al. studied the influence of the main controlling parameters such as drainage conditions, grain size and the confining pressure, in the design of stone columns through a series of laboratory experiments [4]. They mentioned that for installation of group of columns, some procedure was adopted. Enough care was taken to keep the stone columns in vertical position. In clay bed the stone columns were prepared from edges towards the centre. Also, they conducted for two spacing; $2.5 \mathrm{~d}$ and $3 \mathrm{~d}$ ( $\mathrm{d}$ is the stone column diameter), and found that load carrying capacity increased as spacing between the columns is decreased. $\mathrm{Hu}$ et al. mentioned that the area replacement percent is considered effective if it is between $10 \%$ to $30 \%$, and, for the percent of less than $10 \%$, no significant improvement in the ground properties is achieved; whereas, there would be installation difficulties for the area replacement percent more than 30\% [5]. 
The construction of tunnels is a subject of considerable importance to geotechnical and structural engineers. The study of the behavior of these structures, such as transportation tunnels, pipe lines, and ... etc. in layered soil including soft clay layer is considered one of the most important problem in geotechnical engineering, thus due to construction of tunnel lining in layered soil including soft clay layer which considered one of the problematic soil. Many geotechnical challenges are expected to occur related to soft clay layer, especially, when this layer exists around tunnel opening. One of these problems arises when the tunnel is constructed in layered soil due to compressibility of soft soil, especially if soft soil lies around or below tunnel opening. The critical position of soft clay layer when it lies at tunnel level and it has been found that the wariest case when the whole tunnel opening lies inside soft clay layer [6]. To control and mitigate the potential problem, the national authority for tunnels (NAT) has applied grouting to the soil around the tunnel lining. Consequently, the measured settlement in the field when the tunnel construction advanced was found to be significantly less than the estimated value without grouting and well within the allowable limit of $10 \mathrm{~mm},[7]$. Many problems related to the soil and tunnel stability are expected during the construction of the tunnels in layered soil including soft clay. These main problems include large settlements, deformations and increasing in internal forces (normal force, shearing force and bending moment) and stresses in soil. In this study, a technique to improve the behavior of tunnels constructed in layered soil including soft clay layer using stone columns has been presented. This study has been carefully conducted using a 2-D finite element model.

In this study, many cases of stone column positions constructed in layered soil have been considered to represent most expected improvement possible cases were studied. These cases depend on the horizontal distance between stone columns, (center lines spacing). The major objectives of this research are: (i) determination the effect of stone columns to improve the behavior of tunnel lining constructed in layered soil including soft clay layer, (ii) determination the effect of the distance between stone columns on the behavior of tunnel lining, (iii) determination the changes in internal forces in tunnel lining due to existence of stone columns in soft clay layer, and (iv) try to know the critical cases of study to take into consideration to improve soil-tunnel behavior.

\section{FINITE ELEMENT MODEL}

The finite element computer program FINAL [8] has been used in this study. This finite element model takes into account the effects of the vertical overburden pressure and the lateral earth pressure using two methods of solution, Dead Loads or Initial Stresses, in this analysis, Dead Loads method has been used. Also, this program takes into account the nonlinear properties of the soils and the linear properties of tunnel lining. Figure 1 shows the layout of 2-D soil-tunnel model and the used boundary conditions.

The model has a width of $54.0 \mathrm{~m}$ and a height of $50.0 \mathrm{~m}$ including tunnel lining. The finite element model is shown in Figure 2. In addition, the dimensions of the 2-D model have been determined in order to eliminate the size effect in the prediction of the performance of tunnel lining. The soils, tunnel lining and the grouting are simulated using appropriate finite elements. A finite element model for soil, 
grouting, and tunnel lining for soil-tunnel interaction model was built. The soils and grouting were modeled using the 2-D elements, called LST elements, (Linearly Varying Strain Triangular Element), whereas, a tunnel lining was modeled using another 2-D elements, called BEAM 6 elements. Both BEAM 6 and LST elements have six nodes, each having two translation degrees of freedom [9], as shown in Figure 3. Calculations are carried out on the assumption that the tunnel lining is perfectly bonded to the surrounding grouting, which actually bonded to the surrounding soils. BEAM 6 element provides an acceptable solution for the finite element modeling problem, as it considers all possible deformations of tunnel lining. The advantages of this element are that, (i) it can describe the real behavior of the lining as an arched frame, (ii) it can combine with LST finite elements used for grouting, soils and improved soil having stone columns, (in this case it combines with LST grouting elements), and (iii) the number of elements required to model the lining with an acceptable accuracy is very small [10]. The model consists of 36 BEAM-6 elements, 72 LST elements for grouting, 2120 LST elements for soil outside the opening and 164 LST elements for soil inside the opening (before excavation of tunnel). Many studies have been presented to investigate the behavior of different structures in soft soil [11, 12, and 13].

Analysis of deformations or displacements in tunnel lining, grouting and soils, also, internal forces in tunnel lining was carried out using a 2-D plane strain finite element taking into consideration the linear elastic behavior of tunnel lining and plastic behavior of the ground materials [14].

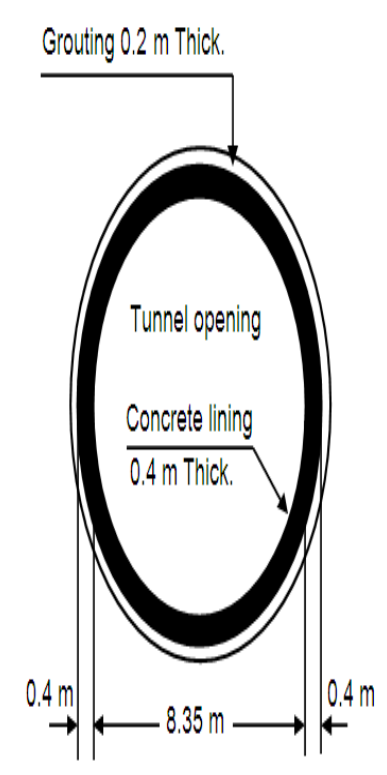

Tunnel dimensions

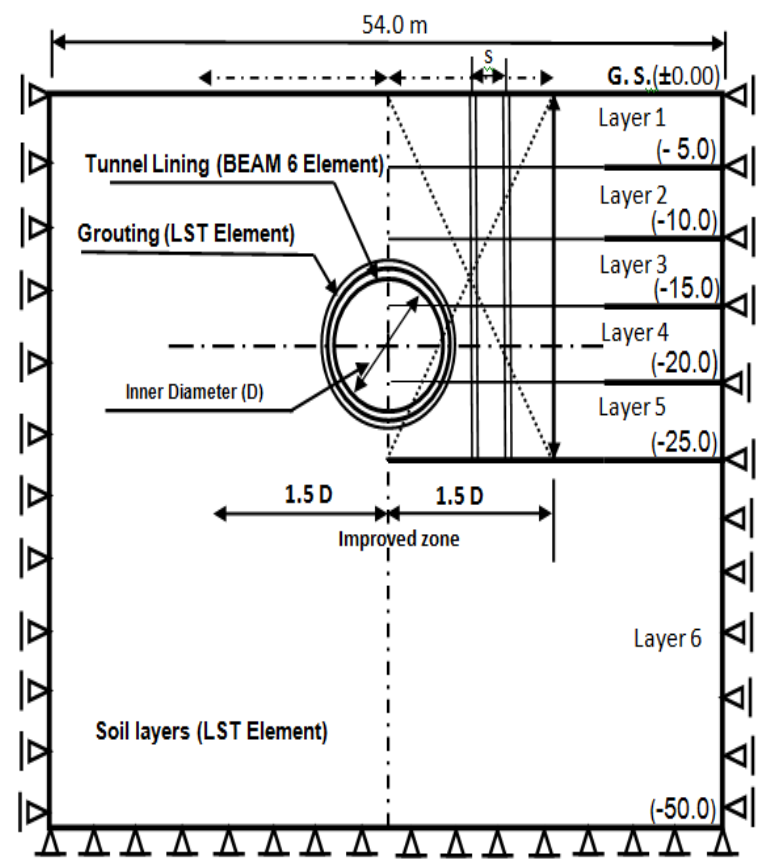

Figure 1. Layout of the model 


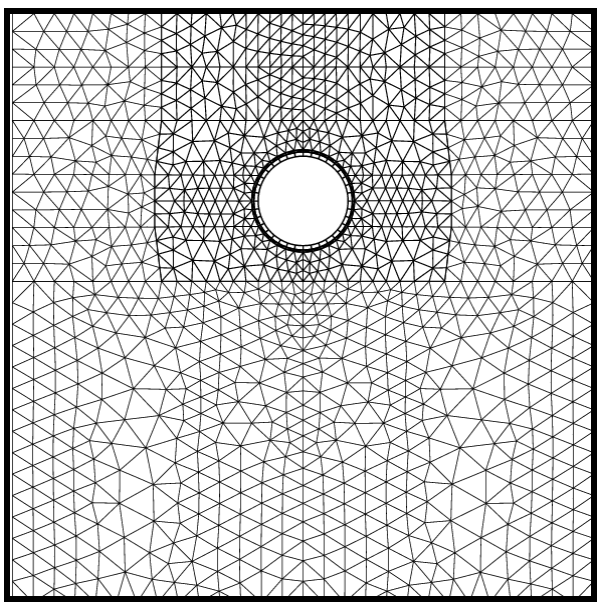

Figure 2. Finite element model

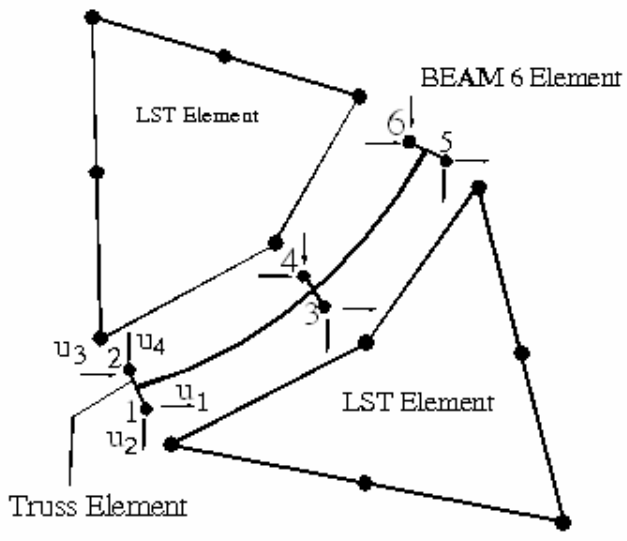

Figure 3: Combined action between BEAM 6 and LST elements [9]

\subsection{Study Cases}

A cross section of tunnel opening is a circle has inner diameter (D) of $8.35 \mathrm{~m}$ and 0.40 $\mathrm{m}$ concrete lining thickness. A tunnel opining is surrounded with $0.20 \mathrm{~m}$ thickness grouting material. Soft clay layer has $15.0 \mathrm{~m}$ thickness and its center line is the same that of $t$ opening. A zone around the tunnel opening has 1.5 times internal diameter of tunnel has been improved using stone columns. In this study, five cases were investigated, first case concerned with the initial case which the original soil layers as shown in Figure 1, do not include any soft clay layer, second case concerned with soil layers and include soft clay layer but without improvement, then, three cases of improvement zone around the tunnel opening with stone columns depending on its columns intensity according to spacing between stone columns were investigated as show in Figure 4 [15].
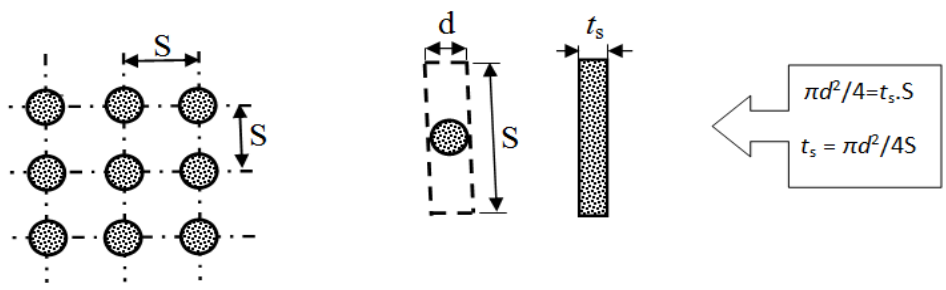

Figure 4: Idealization of stone columns in plane strain [15]

In this investigation, it was assumed that both the stone columns and the surrounding soft clay are the same amount of settlement. There are no interface elements placed between the stone columns and surrounding soil and this is realistic because the stone columns poured against the soil form a very rough interface. The details of study case are presented in Table 1. 


\section{Table 1. Details of the study cases}

\begin{tabular}{|c|c|c|c|c|c|}
\hline \multirow{2}{*}{ Study case } & \multicolumn{3}{|c|}{ Soft clay layer } & \multicolumn{2}{c|}{ Stone columns } \\
\cline { 2 - 6 } & Position & C.L. level & H (m) & d (m) & Spacing S (m) \\
\hline $\begin{array}{c}\text { Case I } \\
\text { (Initial case) }\end{array}$ & $\begin{array}{c}\text { Layers } \\
3+4+5\end{array}$ & $(-17.5 \mathrm{~m})$ & 15.0 & 0.0 & $\begin{array}{c}\text { No stone columns } \\
\text { original soil without } \\
\text { soft clay layer) }\end{array}$ \\
\hline $\begin{array}{c}\text { Case II } \\
\text { (soft layer) }\end{array}$ & $\begin{array}{c}\text { Layers } \\
3+4+5\end{array}$ & $(-17.5 \mathrm{~m})$ & 15.0 & 0.0 & $\begin{array}{c}\text { No stone columns } \\
\text { original soil with } \\
\text { soft clay layer) }\end{array}$ \\
\hline Case III & $\begin{array}{c}\text { Layers } \\
3+4+5\end{array}$ & $(-17.5 \mathrm{~m})$ & 15.0 & 0.6 & 3.0 (Improved case) \\
\hline Case IV & $\begin{array}{c}\text { Layers } \\
3+4+5\end{array}$ & $(-17.5 \mathrm{~m})$ & 15.0 & 0.6 & 2.4 (Improved case) \\
\hline Case V & $\begin{array}{c}\text { Layers } \\
3+4+5\end{array}$ & $(-17.5 \mathrm{~m})$ & 15.0 & 0.6 & 1.8 (Improved case) \\
\hline
\end{tabular}

Where C.L. is the center line of soft clay layer or tunnel opening.

$H$ is the soil thickness of soft clay layer,

$d$ is the inner diameter of stone column, and

$S$ is the centre line distance between stone columns (spacing).

\subsection{Material Constants}

The material constants of tunnel line-2 of Cairo Metro, Egypt, at Km 4.234, were chosen for this study to represent the real practical properties of soil profile. These properties such as modulus of elasticity $(E)$, Poisson's ratio $(v)$, density $(\gamma)$, angle of internal friction $(\phi)$, cohesion $(C)$ and compressive strength $\left(F_{c}\right)$ for different elements of the model [16], are tabulated in Table 2. The properties and position of soft clay layer are reasonably assumed to represent a critical case of study ${ }^{12}$ which may be occurred in practical field, especially; soft clay soil always spreads in many regions in Egypt, and makes many problems in underground constructions

Table 2. The material properties of model (Initial case I)

\begin{tabular}{|l|c|c|c|c|c|c|c|c|}
\hline $\begin{array}{c}\text { Material } \\
\text { properties }\end{array}$ & $\begin{array}{c}\text { Soil } \\
\text { Layer }\end{array}$ & $\begin{array}{c}\text { Soil } \\
\text { Layer } \\
\mathbf{2}\end{array}$ & $\begin{array}{c}\text { Soil } \\
\text { Layer } \\
\mathbf{3}\end{array}$ & $\begin{array}{c}\text { Soil } \\
\text { Layer } \\
\mathbf{4}\end{array}$ & $\begin{array}{c}\text { Soil } \\
\text { Layer } \\
\mathbf{5}\end{array}$ & $\begin{array}{c}\text { Soil } \\
\text { Layer } \\
\mathbf{6}\end{array}$ & $\begin{array}{c}\text { Conc. } \\
\text { Lining } \\
\mathbf{0 . 4 m} \\
\text { Thick. }\end{array}$ & $\begin{array}{c}\text { Grouting } \\
\mathbf{0 . 2} \mathbf{m} \\
\text { Thick. }\end{array}$ \\
\hline$E\left(\mathrm{KN} / \mathrm{m}^{2}\right)$ & $6.0 \mathrm{E} 6$ & $9.0 \mathrm{E} 6$ & $36.0 \mathrm{E} 6$ & $80.0 \mathrm{E} 6$ & $95.0 \mathrm{E} 6$ & $16.0 \mathrm{E} 7$ & $33.5 \mathrm{E} 9$ & $1.1 \mathrm{E} 9$ \\
\hline$v$ & 0.40 & 0.40 & 0.35 & 0.30 & 0.30 & 0.30 & 0.18 & 0.29 \\
\hline$\gamma\left(\mathrm{KN} / \mathrm{m}^{3}\right)$ & 18.0 & 18.5 & 19.0 & 20.0 & 20.0 & 20.0 & 25.0 & 22.0 \\
\hline$\phi$ & 20.0 & 20.0 & 30.0 & 35.0 & 35.0 & 37.0 & - & 00.0 \\
\hline $\begin{array}{c}C \\
\left(\mathrm{KN} / \mathrm{m}^{2}\right)\end{array}$ & 50.0 & 00.0 & 00.0 & 00.0 & 00.0 & 00.0 & - & 00.0 \\
\hline$F_{c}(\mathrm{Mpa})$ & - & - & - & - & - & - & 100.0 & - \\
\hline
\end{tabular}


In the case of any layer which is taken as soft clay one, its properties will be taken as shown in Table 3.

Table 3. Average properties of soft clay layer and improved soil.

\begin{tabular}{|c|c|c|c|c|c|c|}
\hline \multicolumn{2}{|c|}{ Material properties } & $\begin{array}{c}E \\
\left(\mathrm{KN} / \mathrm{m}^{2}\right)\end{array}$ & $v$ & $\begin{array}{c}\gamma \\
\left(\mathrm{KN} / \mathrm{m}^{3}\right)\end{array}$ & $\phi$ & $C\left(\mathrm{KN} / \mathrm{m}^{2}\right)$ \\
\hline \multicolumn{2}{|c|}{ Soft clay layer } & $36.0 \mathrm{E} 5$ & 0.30 & 18.5 & 00.0 & 25.0 \\
\hline \multirow{3}{*}{$\begin{array}{c}\text { Soil improved } \\
\text { with stone } \\
\text { columns }\end{array}$} & Case III & $36.0 \mathrm{E} 6$ & 0.35 & 19.5 & 30.0 & 15.0 \\
\cline { 2 - 7 } & Case IV & $100.0 \mathrm{E} 6$ & 0.37 & 20.0 & 35.0 & 10.0 \\
\cline { 2 - 7 } & Case V & $160.0 \mathrm{E} 6$ & 0.40 & 20.5 & 42.0 & 5.0 \\
\hline
\end{tabular}

\section{ANALYSIS OF RESULTS AND DISCUSSIONS}

The behavior of tunnel lining due to existing of soft clay layer around the opening (all tunnel opening is passing through the soft clay layer as shown in Figure 1) has been studies before ${ }^{1}$. It has been found that this case represents the worst case of study. To study the behavior improvement of the tunnel lining, the stone columns have been installed vertically down in soil layers as bore holes having $0.6 \mathrm{~m}$ diameter $(d)$ reached to below invert point of tunnel opening, then, these bore holes filled with stones. Different three cases of stone columns have been investigated depending on spacing $(S)$ between stone columns. Three different spacing two, three and four times diameter of stone columns $(d)$ have been taken into consideration. The deformations and internal forces including normal forces, shearing forces and bending moments on tunnel lining have been determined. There are critical points on tunnel lining should be carefully studied. These critical points such as Crown, Shoulders_R and L, Spring lines_R and L, Knees_R and L, and Invert which are corresponding to position numbers 1, 2, 8, 3, 7, 4, 6, and 5, respectively, are chosen as shown in Figure 5.

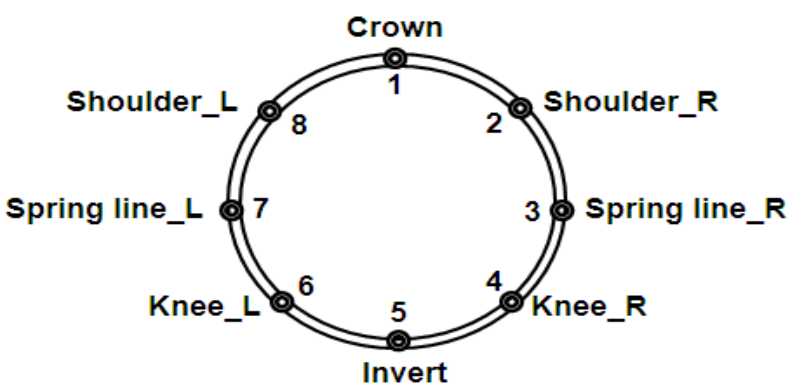

Figure 5: Layout of tunnel lining and critical points (R means Right, and L means Left) 
To analyze and illustrate the behavior of tunnel lining, the obtained results are plotted in the form of deformation shapes, vertical displacements, normal forces, shearing forces, and bending moments.

\subsection{Deformation Shapes and vertical Displacements}

The deformation shapes for tunnel lining and additional vertical displacements for soiltunnel model due to excavation of tunnel in layered soil including soft clay layer at different positions are studied.

\subsubsection{Deformation Shapes}

The deformation shapes of tunnel lining due to excavation of tunnel and soil improving for all cases of study are illustrated as shown in Figure 6. Due to symmetry of loading, the deformation shapes are symmetrically about vertical center line axis of a model, so, it considers only one half model of the tunnel lining.

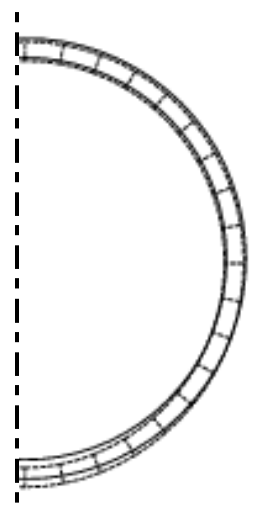

(a) Case I (Initial case)

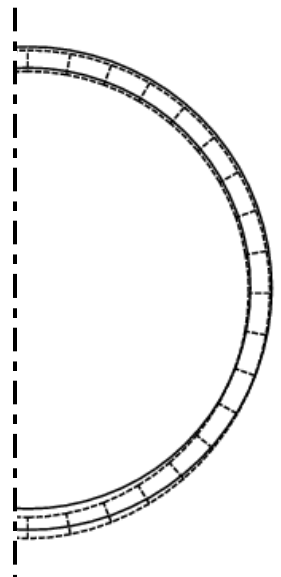

(d) Case IV

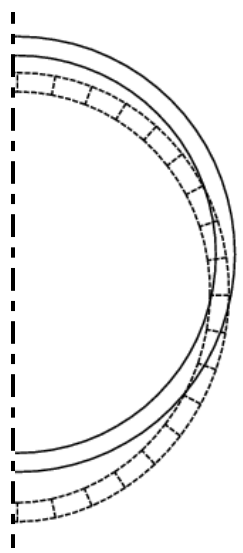

(b) Case II

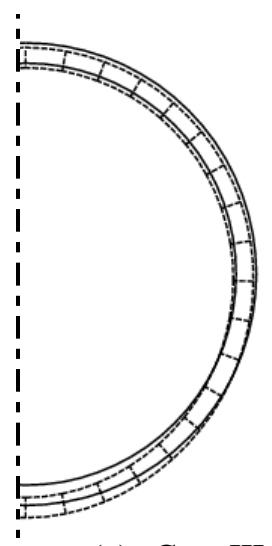

(c) Case III

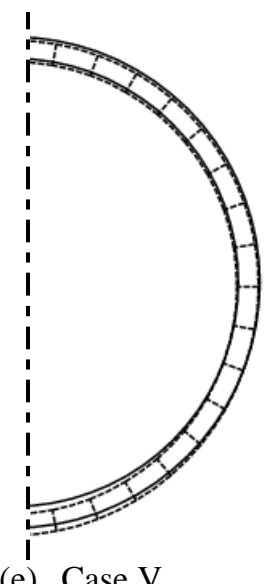

(e) Case V

Figure 6. Deformation shapes of tunnel lining for all cases of study. 
From the deformation shapes of tunnel lining shown in Figure 6, in the cases of layered soil without soft clay (initial case I) and with soft clay (case II), it can be found that, existing of soft clay layer leads to increase the deformation as mentioned by auther $^{6}$. On the other hand, when stone columns were used to improve soft clay in tunnel zone of distance approximately three times of tunnel opening (cases III, IV and $\mathrm{V}$ ), it can be noticed that deformation decreases and back to initial case I. This means that using of stone columns strongly affects on decreasing the deformations in tunnel lining, and this effect depends on spacing between stone columns. Also, it can be found that, the deformations decrease as the spacing between stone columns decreases as shown in Figure 6 (III, IV, and V).

\subsubsection{Vertical Displacements}

The displacements of soil-tunnel model for all cases of study are illustrated as shown in Figure 7. Due to symmetry of loading, the vertical displacements are symmetrically about vertical center line axis of a model, so, it consider only one half model of the tunnel lining.

From the vertical displacements of soil-tunnel shown in Figure 7, in the cases of layered soil without soft clay (initial case I) and with soft clay (case II), it can be found that, the existing of soft clay layer leads to increasing the vertical displacements as mentioned by auther ${ }^{6}$. On the other hand, when stone columns were used to improve soft clay in tunnel zone of distance approximately three times of tunnel opening (cases III, IV and V), it can be noticed that vertical displacement decreases and back to initial case I. This means that using of stone columns strongly affects on decreasing the vertical displacements in soil-tunnel model, and this effect depends on spacing between stone columns. Also, it can be found that, the vertical displacements decrease as spacing between stone columns decreases as shown in Figure 7 (c, d, and e).

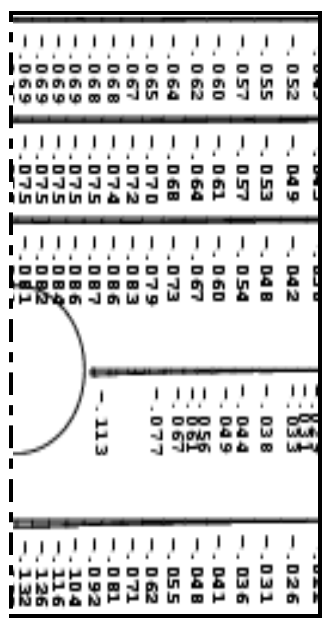

(a) Case I(Initial case)

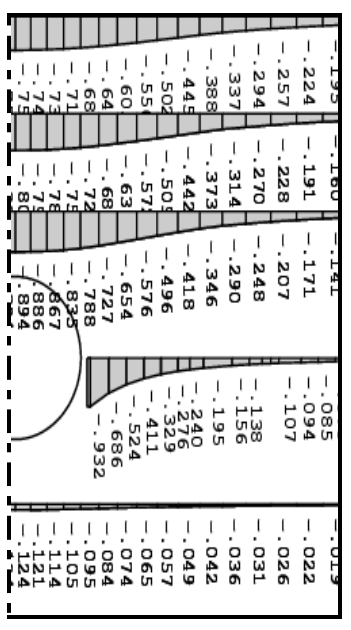

(b) Case II

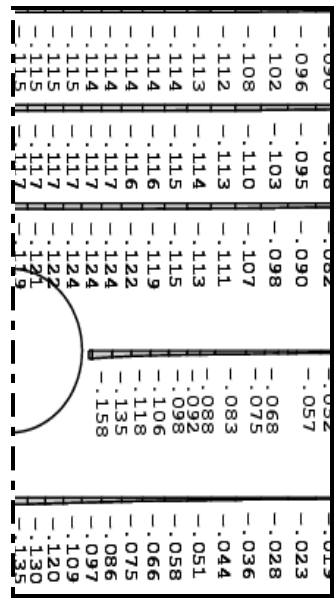

(c) Case III 


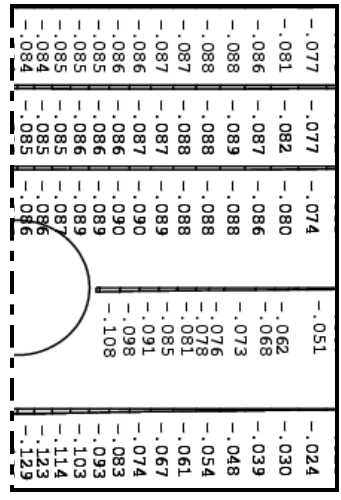

(d) Case IV

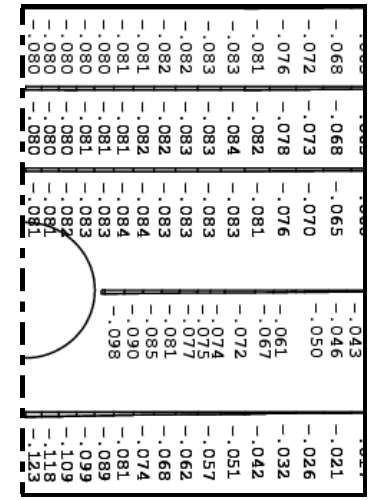

(e) Case V

Figure 7. Vertical displacements of soil-tunnel model for all cases of study.

Table 4. Internal forces in critical tunnel lining points for different studied cases

\begin{tabular}{|c|c|c|c|c|c|}
\hline $\begin{array}{c}\text { Internal forces } \\
\text { (KN) or (KN.m) }\end{array}$ & Case I & Case II & Case III & Case IV & Case V \\
\hline $\mathrm{N}_{1}$ & -419 & 287 & -164 & -263 & -242 \\
\hline $\mathrm{N}_{2}$ & -767 & -116 & -445 & -413 & -322 \\
\hline $\mathrm{N}_{3}$ & -811 & -357 & -689 & -567 & -475 \\
\hline $\mathrm{N}_{4}$ & -431 & -163 & -365 & -358 & -310 \\
\hline $\mathrm{N}_{5}$ & -252 & 302 & -143 & --243 & -221 \\
\hline $\mathrm{N}_{6}$ & -432 & -160 & -364 & -358 & -310 \\
\hline $\mathrm{N}_{7}$ & -773 & -302 & -667 & -567 & -475 \\
\hline $\mathrm{N}_{8}$ & -767 & -116 & -344 & -413 & -316 \\
\hline $\mathrm{Q}_{1}$ & 3 & \pm 7 & \pm 2 & \pm 4 & \pm 3 \\
\hline $\mathrm{Q}_{2}$ & -68 & -112 & -66 & -29 & -17 \\
\hline $\mathrm{Q}_{3}$ & 51 & 24 & 24 & 19 & 3 \\
\hline $\mathrm{Q}_{4}$ & 42 & 117 & 75 & 37 & 27 \\
\hline $\mathrm{Q}_{5}$ & -94 & \pm 86 & \pm 94 & \pm 94 & -92 \\
\hline $\mathrm{Q}_{6}$ & -42 & -119 & -73 & -37 & -14 \\
\hline $\mathrm{Q}_{7}$ & -51 & -24 & -24 & -19 & -16 \\
\hline $\mathrm{Q}_{8}$ & 68 & 109 & 66 & 29 & 20 \\
\hline $\mathrm{M}_{1}$ & 82 & 182 & 73 & 17 & 7 \\
\hline $\mathrm{M}_{2}$ & -30 & -66 & -24 & -7 & 0 \\
\hline $\mathrm{M}_{3}$ & -47 & -182 & -89 & -26 & -12 \\
\hline $\mathrm{M}_{4}$ & 32 & -33 & 37 & 30 & -15 \\
\hline $\mathrm{M}_{5}$ & -36 & 84 & -8 & -47 & -48 \\
\hline $\mathrm{M}_{6}$ & 32 & 32 & 36 & 21 & 16 \\
\hline $\mathrm{M}_{7}$ & -47 & -182 & -89 & -26 & -13 \\
\hline $\mathrm{M}_{8}$ & -30 & -66 & 5 & 1 & 0 \\
\hline & & & & & \\
\hline
\end{tabular}




\subsection{Internal Forces in Tunnel Lining}

For all studied cases considered, the internal forces in tunnel lining, (normal forces, shearing forces and bending moments), are plotted in the following Figures. The internal forces in critical nodes at tunnel lining are tabulated as shown in Table 4.

From Table 4, it can be noticed that, for the same point, compared with initial study case I, value of internal force increases or decreases according to location of point at tunnel lining and intensity of stone columns. Also, it can be found that, in some study cases, at the same point, the normal forces changed from compression to tension and vice versa. Also, values of shear forces and bending moments changed from positive to negative and vice versa.

\subsubsection{Normal Forces}

For all considered study cases, the normal forces are illustrated as shown in Figure 8. This Figure shows a comparison between the normal forces in tunnel lining obtained from initial case (Case I) and other cases.

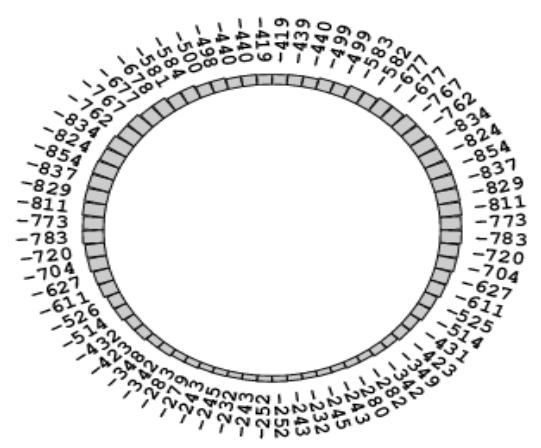

(a) Initial N.F.D. (Case I)

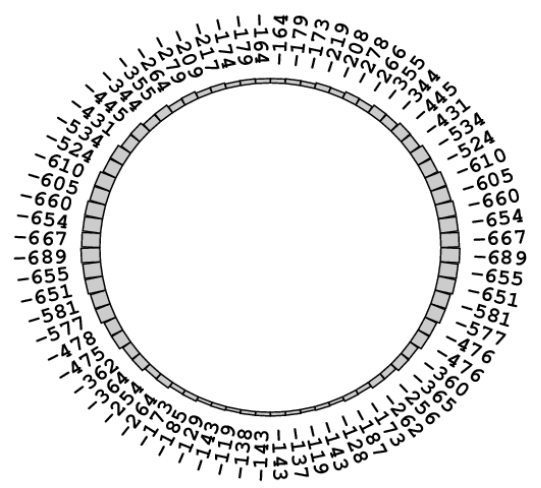

(c) N.F.D. (Case III)

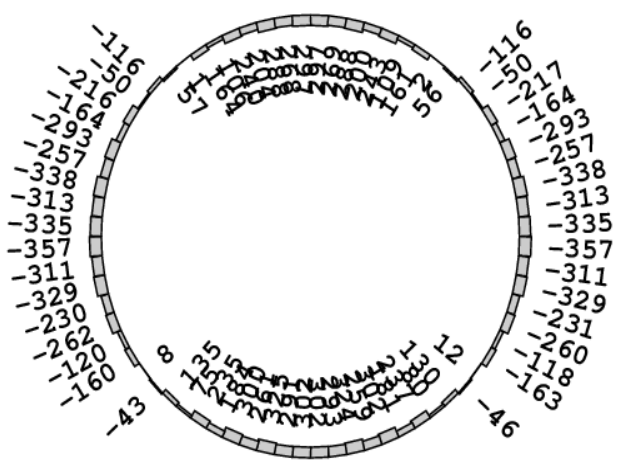

(b) N.F.D. (Case II)

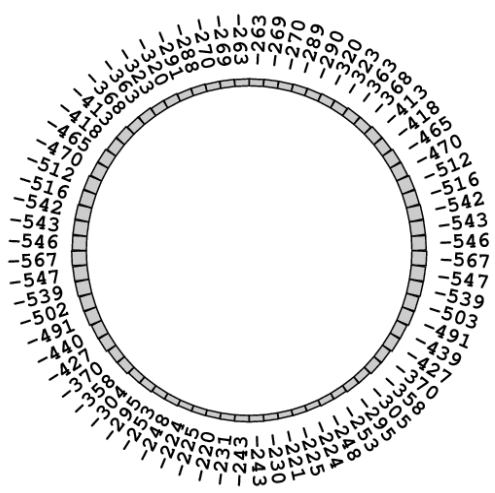

(d) N.F.D. (Case IV) 


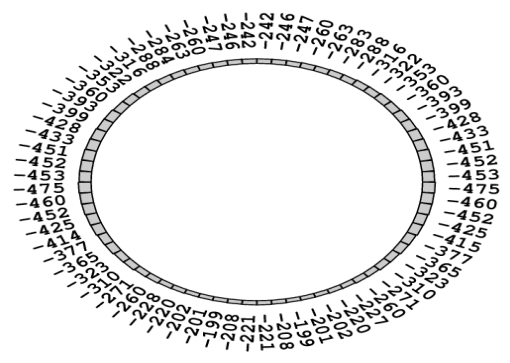

(e) N.F.D. (Case V)

Figure 8. N.F.D in tunnel lining for different study cases.

The effect of soft clay layer on the values of internal normal forces in tunnel lining, (Figure 8 (b)). Whereas, the effect of improving of soft clay layer with installation of stone columns on the values of internal normal forces in tunnel lining is shown in Figures 8 (c, d, e). From initial case I, case II which includes soft clay layer, and other three cases which include improving of soft clay layer with stone columns, it can be noticed that, for case II, the values of normal forces are strongly affected with existence of soft clay layer compared with those obtained from initial case I, but a dangerous problem appeared where at critical points such as Crown and Invert, the values of normal forces are changed from compression to tension as shown in Figure 8(b). On the other hand, in the case of using stone columns, it can be found that the effect of improved soil with stone columns are strongly appeared, where all normal forces are approximately back to become compression and its values are less than those obtained from initial case as shown in Figure 8 (c, d, and e). Also, it can be found that, due to increasing of a stiffness of enhancement zone, normal forces decrease when spacing between stone columns decreases as shown in Figure 8 (c, d, and e).

\subsubsection{Shearing Forces}

For all considered study cases, the shearing forces in tunnel lining are illustrated as shown in Figure 9. This Figure shows a comparison between the shearing forces in tunnel lining obtained from initial case (Case I) and those obtained from other cases.

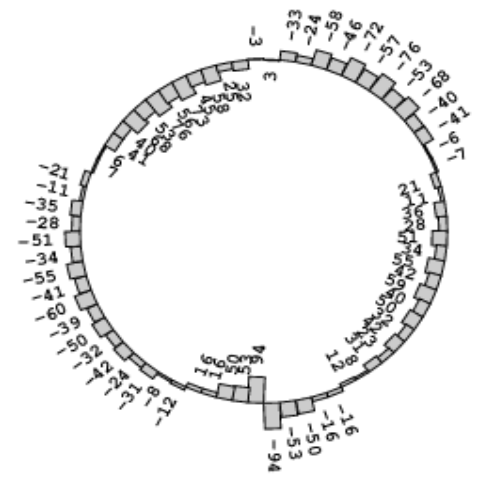

(a) Initial S.F.D. (Case I)

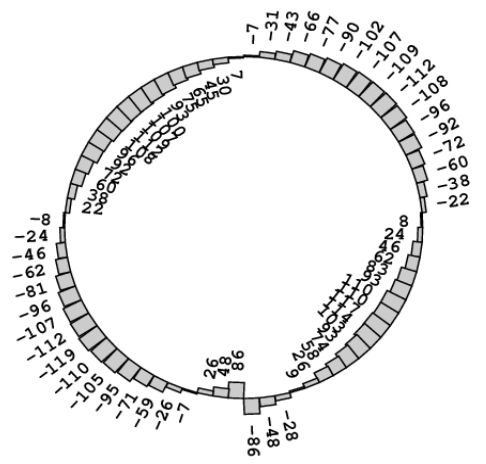

(b) S.F.D. (Case II) 


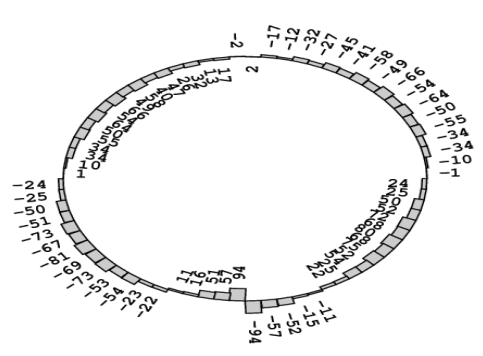

(c) S.F.D. (Case III)

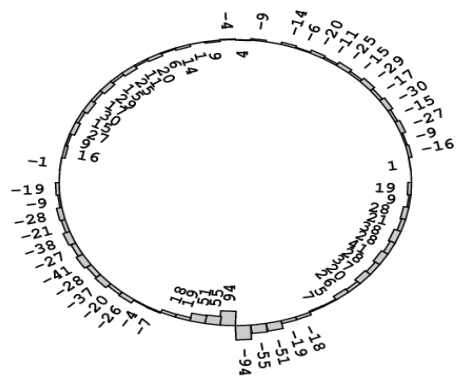

(d) S.F.D. (Case IV)

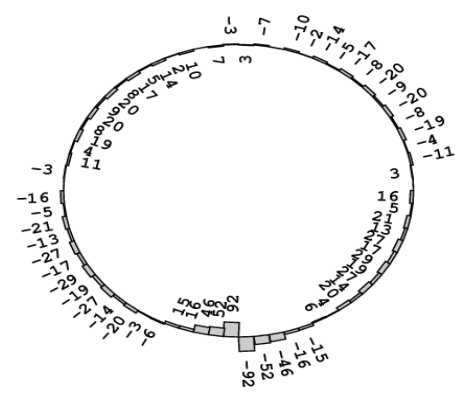

(e) S.F.D. (Case V)

Figure 9. S.F.D in tunnel lining for different study cases.

Figure 9 shows the effect of soft clay layer on the values of internal shearing forces in tunnel lining, (Figure 9 (b)). Whereas, the effect of improving of soft clay layer with installation of stone columns on the values of internal shearing forces in tunnel lining is shown in Figure 9 (c, d, e). From initial case I, case II which includes soft clay layer, and other three cases which include improving of soft clay layer with stone columns, it can be noticed that, for case II, the values of shearing forces are strongly affected with existence of soft clay layer compared with those obtained from initial case I, and the maximum value of shearing force in tunnel lining (at Shoulders) is greater than and approximately 1.55 times that of the initial case I as shown in Figure 9 (b). On the other hand, in the case of using stone columns, it can be found that the effect of improved soil with stone columns are strongly appeared, and the maximum value of shearing force in tunnel lining began to decrease and is smaller than that of the initial case I as shown in Figure 9 (c, d, and e). Also, it can be found that, due to increasing of a stiffness of enhancement zone, shearing forces decrease as spacing between stone columns decreases as shown in Figure 9 (c, d, and e).

\subsubsection{Bending Moment}

For all considered study cases, the bending moments in tunnel lining are illustrated as shown in Figure 10. This Figure shows a comparison between the bending moments in tunnel lining obtained from initial case I and those obtained from other cases.

Figure 10 shows the effect of soft clay layer on the values of internal bending moments in tunnel lining, (Figure 10 (b)). Whereas, the effect of improving of soft clay layer with installation of stone columns on the values of bending moments in tunnel lining is shown in Figure 10 (c, d, e). 


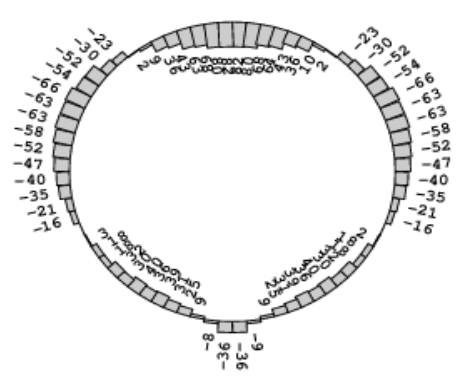

(a) Initial B.M.D. (Case I)

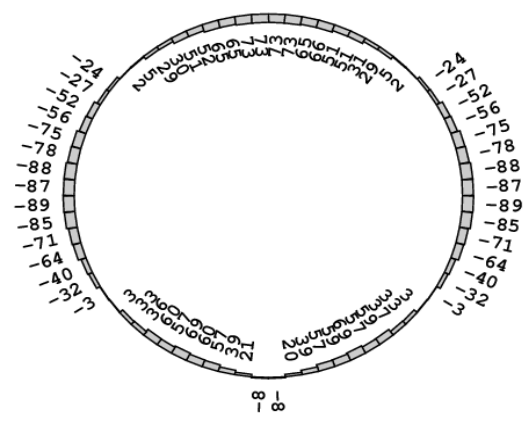

(c) B.M.D. (Case III)

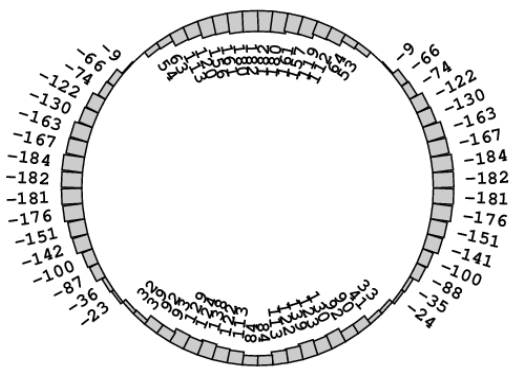

(b) B.M.D. (Case II)

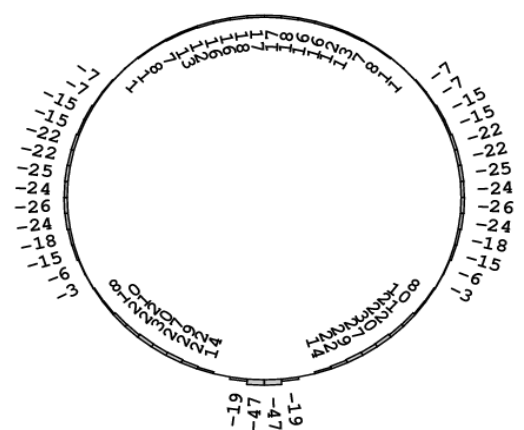

(d) B.M.D. (Case IV)

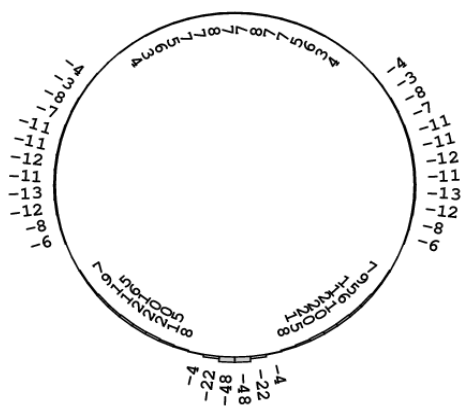

(e) B.M.D. (Case V)

Figure 10. B.M.D in tunnel lining for different study cases.

From initial case I which does not include soft clay layer, case II which includes soft clay layer, and other three cases which include improving of soft clay layer with stone columns, it can be noticed that, for case II, the values of bending moments are strongly affected with existence of soft clay layer compared with those obtained from initial case I, and the maximum value of shearing force in tunnel lining (at Spring lines) is greater than and approximately 3.0 times that of the initial case I as shown in Figure 10 (b). On the other hand, in the case of using stone columns, it can be found that the effect of improved soil with stone columns are strongly appeared, and the maximum value of bending moments in tunnel lining began to decrease and is smaller than that of the initial case I as shown in Figure 10 (c, d, and e). Also, it can be found that, due to increasing of a stiffness of enhancement zone, bending moments decrease as spacing between stone columns decreases as shown in Figure 10 (c, d, e). 


\section{CONCLUSIONS}

The present study is concerned with the improving behavior of tunnel lining constructed in layered soil including soft clay layer using stone columns installation technique. In this study, the main parameters taken into consideration are critical position of soft clay layer corresponding to tunnel opening level and spacing between stone columns. The results obtained from this study are compared with the initial values obtained from a reference layered soil with no soft clay layer.

Based on the above discussion and analysis of obtained results, the following main conclusions are drawn:

(1) The danger of existence of soft clay layer in layered soil around a tunnel opening is that some of internal forces in tunnel lining have been changed in sign from compression to tension or from positive to negative and vice versa.

(2) Using stone columns installation to improving technique causes increasing in a stiffness of enhancement zone around tunnel opening.

(3) Inclusion of stone columns considerably improves the behavior of tunnel lining constructed in layered soil including soft clay layer.

(4) Stone columns decrease vertical displacements in soil-tunnel model, and decrease deformations in tunnel lining.

(5) Stone columns are strongly effect in decreasing the internal forces in tunnel lining.

(6) Spacing of the columns plays an important role in affecting the deformation characteristics and internal forces in tunnel lining. Also, effective increases as spacing decreases.

\section{REFERENCES}

1. Aiban S.A., "Effectiveness of Stone Columns: Field Assessment," Geotechnical Special Publication, Vol., Issue. 116 II, 2002.

2. Dipty S.I. and Girish M.S., "Suitability of Different Materials for Stone Column Construction," EJGE Engineering Journal of Geotechnical Engineering, Vol. 14, 2009.

3. Ambily, A.P. and Gandi S.R, "Behavior of Stone Columns Based on Experimental and FEM Analysis" Journal of Geotechnical and Geoenvironmental Engineering, Vol. 133, pp. 405-415, 2006.

4. Andreou, P., Frikha, W., Canou, J., Papadoopoulos, V., and Dupla J.C, "Experimental Study on Sand and Gravel Columns in Clay", Ground Improvement, Vol. 161, pp. 189-198, 2008.

5. Hu w., Wood D. M., Steward W., "Ground Improvement Using Stone Column Foundation", Result of model tests. Proc. Int. Conf. on Ground Improvement Technique, Macau, pp. 247-256, 1977.

6. Abdel Naiem, M.A. and Abdo, M.A., "Effect of Soft Clay Layer on Behavior of Tunnel Lining Constructed in Layered Soil," JES Journal of Engineering Sciences, Faculty of Engineering, Assiut University, Egypt,Vol. 38, No. 5, pp. 1101-1117, Sept., 2010.

7. Abdel Salam, M.E., "Urban Constraints on Underground Works the Cairo MetroCase Histories," Egyptian Society Presentation, Cairo, 1998. 
8. Swoboda, G. "Program System FINAL- Finite Element Analysis Program for Linear and Nonlinear Analysis," Version 7.1, University of Innsbruck, Austria, 1999.

9. Swoboda, G. "Finite Element Analysis of the New Austrian Tunneling Method," 3rd International Conference on Numerical Methods in Geomechanics, Aachen, pp. 581-586, 1979.

10. Moussa, A., "Finite Element Modelling of shotcrete in tunnelling," Ph.D. Dissertation, University of Innsbruck, Austria, 1993.

11. Wheeler S. J., Naatanaen V. R., Karstunen M., and Lojander M., "An Anisotropic Elastoplastic Model for Soft Clays," Canadian Geotechnical Journal (40), pp. 403-418, 2003.

12. Lee K. M., Manjunath A., and Dewaiker D. M., "Numerical and Model Studies of Strip Footing Support by a Reinforced Granular Fill - Soft Soil System," Canadian Geotechnical Journal (36), pp. 793-806, 1999.

13. Zhang L., "Settlement Patterns of Soft Soil Foundations under Embankments," Canadian Geotechnical Journal (36), pp. 774-781, 1999.

14. Hasan, H. A., El-Nahhas, F. and Belal, A.M. "Analysis of Rock-Lining Interaction for Circular Tunnels using the Finite Element Simulation," Eleventh International Colloquium on Structural and Geotechnical Engineering, ICSGE, Ain Shams, Egypt, 2005.

15. Zahmatkesh and Choobbsti, "Settlement Evaluation of Soft Clay Reinforced by Stone Columns, Considering the Effect of Soil Compaction", IJRRAS 3 (2), pp. 159-166, may 2010.

16. Mansour, M., "Three Dimensional Numerical Modelling of Hydroshield tunneling" Ph. D. Thesis, University of Innsbruck, Austria, 1996.

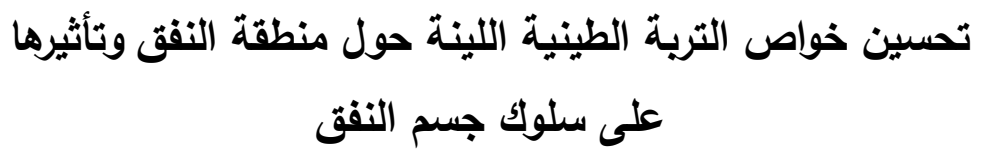

نظراً للحاجة الماسة إلى تطوير البنية التحتية في المدن المزدحة بالسكان والذي ينرتب عليه للازدحام الثديد

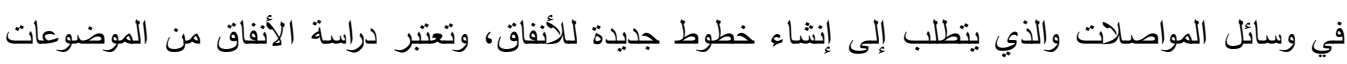

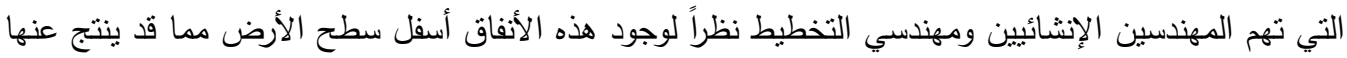

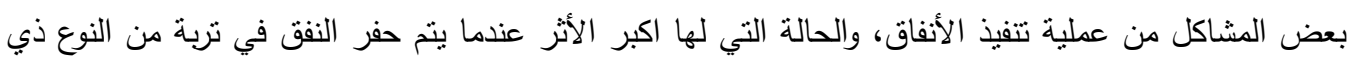

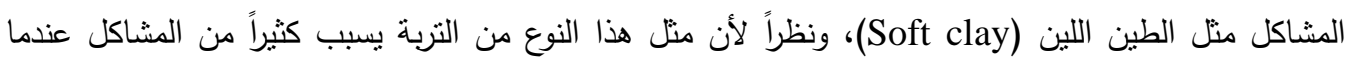

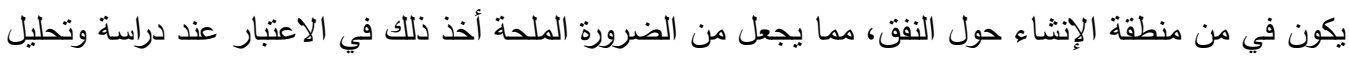
منل هذه المنشآت تحت الأرضية.

من أهم هذه الهشاكل التي يجب أن تؤُخذ في الاعتبار أن الهبوط الناتج من حفر النفق نتيجة وجود طبقة الطين

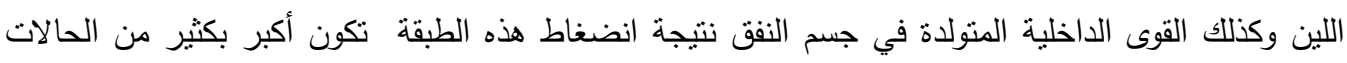

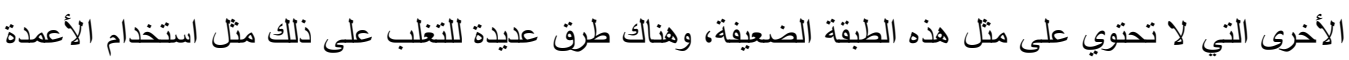
المملوءة بالدجر (Stone columns) التي تعتبر من أنسب الطرق من الناحية العملية والاقتصادية (التكلفة)

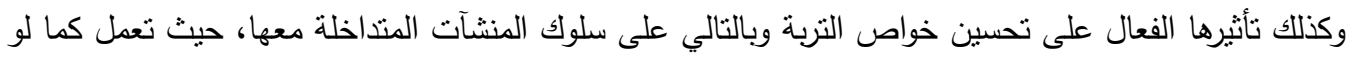


كانت تسليح رأسي للتربة كما أنه عند إنثاء تلك الأعمدة الحجرية تعمل على دمك التربة وبالتالي زيادة قوة تحمل التربة، وهناك عدة متغيرات لها تأثير مباثر على هذه الدراسة منل سمك وموضع طبقة الطين اللين وكذلك المسافة بين الأعمدة الحجرية، وتركزت هذه الدراسة على المتغير الخاص بالمسافة بين الأعمدة الحجرية.

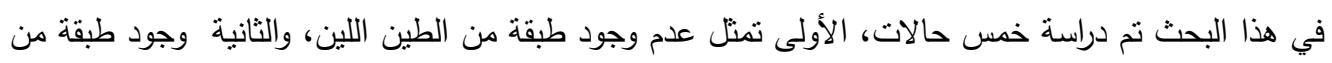
الطين اللين بدون تحسين، والثلاث حالات الباقية تخص تحسين التربة اللينة باستخدام الأعمدة الحجرية معتمدة على المسافة في ما بينها، حيث تمت دراسة ثلاث مسافات خمس وأربع وثناث مرات قطر العمود، وأن المنطقة المحسنة حول النفق حوالي مرة ونصف القطر الخارجي للنفق والني تمنل تقريباً المنطقة حول النفق المؤثرة على ونى سلوكه. ومن أهم النتائج التي نت التوصل إليها من هذا البحث أن وجود طبقة الطين اللين نتج عنه زيادة في مقدار القوى الداخلية لبعض الحالات عن الحالة الأصلية والأخطر من ذلك هو تغير نوع القوى المحورية الداخلية في جسم النفق من ضغط إلى شد والعكس، ومن موجب إلى سالب والعكس في حالة قوى القص وعزوم الانحناء،

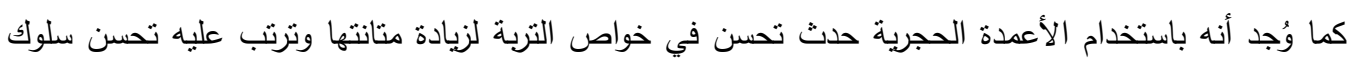
النفق، حيث ساعد على تقليل الهبوط الرأسي وكذلك تقليل التشكلات في جسم النفق مما ترتب عليه تقليل في

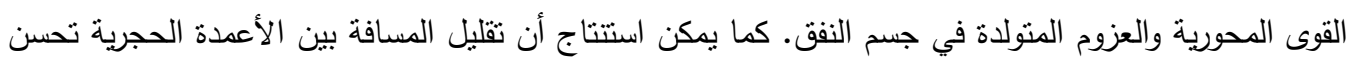
بصورة جيدة خواص التربة وسلوك النفق المحيطة به. 